\title{
INTERNET USAGE AND JUVENILE DELINQUENCY OF HIGH SCHOOL STUDENTS IN SURABAYA INDONESIA
}

\author{
Herdina Indrijati ${ }^{1 *}$, Endah Mastuti ${ }^{1}$ and Prihastuti ${ }^{1}$ \\ ${ }^{1}$ Faculty of Psychology Universitas Airlangga, Indonesia
}

\begin{abstract}
This research aimed to find out differences in juvenile delinquency based on the frequency of internet usage on high school students in Surabaya, Indonesia. Internet usage was measured based on the average frequency of daily use of the internet. Juvenile delinquency is students' tendency to violate regulations which can result in loss and damage both to oneself and others. This research used quantitative approach, involving 498 students from eight different schools in Surabaya, Indonesia. Data collection used internet usage and juvenile delinquency questionnaires. Descriptive statistical analysis and analysis of variance were conducted to analyze the data. The hypothesis testing resulted $\mathrm{F}$ coefficient of 3.125 with significance value of 0.026 , implying that there were marked differences in juvenile delinquency based on the usage frequency of the internet of high school students in Surabaya Indonesia.
\end{abstract}

Keywords: Internet usage, juvenile delinquency, high school students

\section{Introduction}

Internet usage among adolescents keeps increasing alongside with the continuous advancement of technology. Internet users always want to have updated technology, to upgrade their gadget's ability hoping that it will ease their access to the internet. The rapid changes and development in various aspect of the world, particularly in technology, are inevitable. These changes and development have their positive and negative consequences. Among the negative consequences of internet usage is its worrying impact on children and adolescents. The repercussions it may bring will get bigger as the use of the internet gets more intense.

As often reported by the media and studies, among the biggest users of the internet are children and adolescents. The Ministry of Communication and Informatics of Republic of Indonesia (KOMINFO) also reports in its press release No. 17/PIH/KOMINFO/2/2014 concerning a research by KOMINFO and the United Nations Children's Fund (UNICEF) on children and adolescents' behavior in relation to internet access by tracking online activities of children and adolescent sample aged 10 to 19 years old (with a total of 400 respondents) from all across the country, representing both urban and rural areas. The data shows that at least 30 million children and adolescents in Indonesia are users of the internet and that digital media is the current main communication medium of their choice. (http://kominfo.go.id/index.php/content/detail/3834/Siaran+Pers+No.+17PIHKOMINFO-

2014+tentang+Riset+Kominfo+dan+UNICEF+Mengenai+Perilaku+Anak+dan+Remaja+Dalam+Menggunakan +Internet+/0/siaran_pers\#.Vit_Wyub4rE).

Taking this data by KOMINFO into account, one can imagine how much Indonesian children and adolescents have been exposed to the internet each day because the majority of them has their own gadgets which are connected to the internet anywhere and anytime they want. This fairly high exposure to the internet might cause some implications for the youth, including unfavorable behaviors.

Juvenile delinquency is known to have considerably increased in recent years. It can be observed from a data by Indonesia's National Commission for Child Protection (Komnas PA), which indicates an increase in criminal 
behavior among adolescents and children. According to this data, during January and October 2009, there was $35 \%$ rise over the crime rate by young offenders of the previous year. The age of the offenders was ranging from 13 to 17 years old (nusantaraku.com, 2009).

In the East Java province alone, the rate of crime by adolescent offenders is quite worrying. The Central Bureau of Statistic of East Java province recorded a growth in the number of criminal and drug cases by children under 21 years old each year, as shown in the Table 1 below:

Table 1 Number of Criminal and Drug Cases by Adolescents in East Java

\begin{tabular}{lll}
\hline Year & Juvenile Delinquency & Drug Case \\
\hline 2005 & - & 115 \\
\hline 2006 & 11 & 70 \\
\hline 2007 & 56 & 152 \\
\hline 2008 & 45 & 22 \\
\hline 2009 & - & 16 \\
\hline
\end{tabular}

Source: Central Bureau of Statistics of East Java Province

The data shown in Table 1 indicates that adolescents' deviant behavior has become increasingly apprehensive. According to Sarwono (2010), every behavior which deviates from the social norms within a community (e.g. religious norms, ethics, school and family regulations, etc.) can be classified into deviant behavior (deviation). When a deviant behavior violates the law, it is then deemed as juvenile delinquency.

As Young (1998) suggests, excessive use of the internet can lead to negative experience. Students with internet addiction are very likely to play truant, to be disobedient to parents for playing games, to be addicted to social media, and to conduct other juvenile delinquencies. Ma, et.al (2011) found that delinquent Internet use was likewise associated positively with delinquent daily social behavior at chinese adolescent. Ma, et.al (2011) also found that boys were more delinquent in daily behavior than were girls. Boys spent more time using the Internet each week than did girls. Perhaps this finding is related to the fact that Chinese people tend to have higher expectations in the educational achievements of boys than of girls, and boys are often given more opportunities and resources than are girls

In this study, researchers want to know whether there are various diliquency behavior in adolescents based on internet usage.

\section{Hypothesis}

Ha: There are significant differences in juvenile delinquency based on usage frequency of the internet on high school students in Surabaya, Indonesia.

\section{Method}

In term of methodology, this research used quantitative approach.

\section{Operationalization of the Research Variables}

1. Internet usage is Internet usage in this case is the average duration of internet usage on a daily basis. This research also classified it into three categories, namely low (an hour or less), moderate (2-3 hours), high (4 hours or more) in a day.. This variable is measured by Internet Usage Questionaire. 
2. Juvenile delinquency is adolescents' tendency to behave in particular fashions which violate regulations and can cause loss and damage both to oneself and others. This variable is measured by Juvenile delinquency scale

Subject: Subjects of this research were youth in early to middle adolescence. The total of subjects involved in this research is 498 adolescents.

\section{Data Collection Technique}

The data collection in this research utilized some scales. The scales used Likert-scaling techniques and are enlisted as follow : (1) Internet usage scale, (2) Juvenile delinquency scale. The validation techniques was content validity, and reliability test using alpha Cronbach techniques resulted in alpha of 0,927. This scale developed by Aroma (2012). The indicators of the trends scale of juvenile delinquency scale include: 1 . Target That is the cognitive pattern of opinion or individual attitudes that lead to the behavior of juvenile delinquency 2. Action That is the behavior of individuals who begin to lead to the behavior of juvenile delinquency 3 . Context It is an environment that lacks social control, a place for rogue children, or an environment with bad stimuli 4. Time Referring to certain times when teenagers tend to do delinquent behavior

Data Analysis: The data was analysis using descriptive statistical analysis via SPSS program. In order to test the hypothesis, Analysis of variance was also run.

\section{Result and Discussion}

\section{Descriptive Data}

The sample pool of current research consisted of 498 students from eight different high schools in Surabaya. Detailed distribution of the subjects is shown in Table 2 to Table 9 below:

Table 2 Subject Distribution Based on School of Origin

\begin{tabular}{|c|c|c|}
\hline Type of School & Total & Percentage $(\%)$ \\
\hline 1 Public High School & 60 & 12.04 \\
\hline 4 Private High Schools & 245 & 49.19 \\
\hline 2 Public Vocational High Schools & 133 & 26.7 \\
\hline 1 Private Vocational High School & 60 & 12.04 \\
\hline Total & & \\
\hline
\end{tabular}

Table 3 Subject Distribution Based on Age

\begin{tabular}{lll}
\hline Age & Total & Percentage $(\%)$ \\
\hline 14 years old & 21 & 2.81 \\
\hline 15 years old & 139 & 27.91 \\
\hline 16 years old & 183 & 36.74 \\
\hline 17 years old & 143 & 28.71 \\
\hline 18 years old & 10 & 2.008 \\
\hline Missing data & 2 & \\
\hline Total & 498 & \\
\hline
\end{tabular}


Table 4 Subject Distribution Based on Sex

\begin{tabular}{lll}
\hline Sex & Total & Percentage (\%) \\
\hline Male & 228 & $37 \%$ \\
\hline Female & 265 & $63 \%$ \\
\hline Missing data & 5 & \\
\hline Total & 498 & \\
\hline
\end{tabular}

Table 5 Frequency of Internet Usage in a Month

\begin{tabular}{lll}
\hline Frequency & Total & Percentage (\%) \\
\hline Everyday & 420 & 84.33 \\
\hline Twice a week & 34 & 6.83 \\
\hline Every week & 18 & 3.61 \\
\hline Every month & 12 & 2.41 \\
\hline Other & 14 & 2.81 \\
\hline
\end{tabular}

Table 6 Duration of Internet Usage in a Day

\begin{tabular}{lll}
\hline Duration & Total & Percentage (\%) \\
\hline Less than an hour & 40 & 8.03 \\
\hline An hour & 48 & 8.63 \\
\hline 2 (two) hours & 74 & 14.85 \\
\hline 3 (three) hours & 70 & 14.05 \\
\hline 4 (four) or more hours & 258 & 51.8 \\
\hline
\end{tabular}

Table 7 Daily Frequency of Internet Usage

\begin{tabular}{lll}
\hline Frequency & Total & Percentage $(\%)$ \\
\hline Low & 88 & 17,67 \\
\hline Moderate & 149 & 29,91 \\
\hline High & 259 & 52 \\
\hline
\end{tabular}

Table 8 Purpose of Using the Internet

\begin{tabular}{llll}
\hline Purpose & Type & Total & Percentage (\%) \\
\hline \multirow{2}{*}{ Email communication } & To read emails & 195 & 39.16 \\
\cline { 2 - 4 } & To send emails & 204 & 40.96 \\
\cline { 2 - 4 } & Other & 79 & 15.86 \\
\hline \multirow{2}{*}{ Chatting } & WhatsApp (WA) & 134 & 26.91 \\
\cline { 2 - 4 } & BlackBerry Messengers (BBM) & 418 & 83.94 \\
\cline { 2 - 4 } & LINE & 386 & 77.51 \\
\cline { 2 - 4 } & Facebook (FB) & 219 & 43.98 \\
\cline { 2 - 4 } & Other & 12 & 2.41 \\
\hline \multirow{2}{*}{ Social media access } & Facebook (FB) & 302 & 60.64 \\
\cline { 2 - 4 } & Twitter & 103 & 20.68 \\
\cline { 2 - 4 } & Path & 77 & 15.46 \\
\hline & Instagram & 391 & 78.51 \\
\hline & Other & 12 & 2.41 \\
\hline
\end{tabular}


Table 9 Descriptive of Internet Usage and Juvenile Delinquency

\begin{tabular}{|c|c|c|c|c|c|c|c|c|}
\hline & \multirow{2}{*}{$\mathrm{N}$} & \multirow{2}{*}{ Mean } & \multirow{2}{*}{$\begin{array}{l}\text { Standard } \\
\text { Deviation }\end{array}$} & \multirow{2}{*}{$\begin{array}{l}\text { Standard } \\
\text { Error }\end{array}$} & \multicolumn{2}{|c|}{$\begin{array}{l}95 \% \text { Confidence } \\
\text { Interval for Mean }\end{array}$} & \multirow{2}{*}{ Minimum } & \multirow{2}{*}{ Maximum } \\
\hline & & & & & $\begin{array}{l}\text { Lower } \\
\text { Bound }\end{array}$ & $\begin{array}{l}\text { Upper } \\
\text { Bound }\end{array}$ & & \\
\hline Missing data & 2 & 65.5000 & .70711 & .50000 & 59.1469 & 71.8531 & 65.00 & 66.00 \\
\hline Low & 89 & 72.4270 & 14.25808 & 1.51135 & 69.4235 & 75.4305 & 44.00 & 114.00 \\
\hline Moderate & 148 & 67.1622 & 13.20588 & 1.08552 & 65.0169 & 69.3074 & 39.00 & 106.00 \\
\hline High & 259 & 68.5483 & 12.61999 & .78417 & 67.0041 & 70.0924 & 43.00 & 119.00 \\
\hline Total & 498 & 68.8173 & 13.17140 & .59022 & 67.6576 & 69.9769 & 39.00 & 119.00 \\
\hline
\end{tabular}

\section{Hypothesis Testing}

The hypothesis testing resulted in $\mathrm{F}=3.125$ with significance value of 0.026 which implied that "There are significance differences in juvenile delinquency based on internet usage", detailed result is as follows:

Table 10 Analysis of Variance

ANOVA

Juvenile Delinquency

\begin{tabular}{lccccc}
\hline & Sum of Square & df & Mean Square & F & Significance \\
\hline Between Groups & 1605.841 & 3 & 535.280 & 3.125 & .026 \\
\hline Within Groups & 84616.530 & 494 & 171.289 & & \\
\hline Total & 86222.371 & 497 & & & \\
\hline
\end{tabular}

Table 11. Multiple Comparisons

\begin{tabular}{|c|c|c|c|c|c|c|c|}
\hline LSD & & & & & & & \\
\hline & & & Mean & & & $95 \%$ Conf & nce Interval \\
\hline $\begin{array}{l}\text { Dependent } \\
\text { Variable }\end{array}$ & (I) Internet & (J) Internet & $\begin{array}{l}\text { Difference (I- } \\
\text { J) }\end{array}$ & Std. Error & Sig. & Lower Bo & d Upper Bound \\
\hline Prokrastinasi & .00 & rendah & 1.3315 & 3.43164 & .698 & -5.4110 & 8.0739 \\
\hline & & sedang & .9189 & 3.41658 & .788 & -5.7939 & 7.6317 \\
\hline & & tinggi & .8668 & 3.40680 & .799 & -5.8268 & 7.5604 \\
\hline & rendah & .00 & -1.3315 & 3.43164 & .698 & -8.0739 & 5.4110 \\
\hline & & sedang & -.4125 & .64378 & .522 & -1.6774 & .8523 \\
\hline & & tinggi & -.4647 & .58971 & .431 & -1.6233 & .6940 \\
\hline & sedang & .00 & -.9189 & 3.41658 & .788 & -7.6317 & 5.7939 \\
\hline & & rendah & .4125 & .64378 & .522 & -.8523 & 1.6774 \\
\hline & & tinggi & -.0521 & .49455 & .916 & -1.0238 & .9196 \\
\hline & tinggi & .00 & -.8668 & 3.40680 & .799 & -7.5604 & 5.8268 \\
\hline & & rendah & .4647 & .58971 & .431 & -.6940 & 1.6233 \\
\hline & & sedang & .0521 & .49455 & .916 & -.9196 & 1.0238 \\
\hline kenakalan & .00 & rendah & -6.9270 & 9.35782 & .460 & -25.3130 & 11.4591 \\
\hline & & sedang & -1.6622 & 9.31674 & .858 & -19.9675 & 16.6432 \\
\hline & & tinggi & -3.0483 & 9.29008 & .743 & -21.3012 & 15.2047 \\
\hline & rendah & .00 & 6.9270 & 9.35782 & .460 & -11.4591 & 25.3130 \\
\hline
\end{tabular}


Herdina Indrijati et al / Internet Usage And Juvenile Delinquency Of......

\begin{tabular}{llllllll}
\hline & sedang & $5.2648^{*}$ & 1.75555 & .003 & 1.8155 & 8.7141 \\
\cline { 2 - 7 } & tinggi & $3.8787^{*}$ & 1.60808 & .016 & .7192 & 7.0382 \\
\cline { 2 - 7 } sedang & .00 & 1.6622 & 9.31674 & .858 & -16.6432 & 19.9675 \\
\cline { 2 - 7 } & rendah & $-5.2648^{*}$ & 1.75555 & .003 & -8.7141 & -1.8155 \\
\cline { 2 - 7 } & tinggi & -1.3861 & 1.34859 & .305 & -4.0358 & 1.2636 \\
\cline { 2 - 7 } & \multirow{2}{*}{ tinggi } & .00 & 3.0483 & 9.29008 & .743 & -15.2047 & 21.3012 \\
\cline { 2 - 7 } & rendah & $-3.8787^{*}$ & 1.60808 & .016 & -7.0382 & -.7192 \\
\cline { 2 - 7 } & sedang & 1.3861 & 1.34859 & .305 & -1.2636 & 4.0358 \\
\hline
\end{tabular}

Based on observed means.

The error term is Mean Square(Error) $=171.289$.

*. The mean difference is significant at the

Based on the hypothesis testing and the means obtained from the descriptive data, the result indicated that the three groups of internet usage showed different juvenile delinquency. The group with high frequency of internet usage, which was more than four hours a day, had juvenile delinquency tendency score of 68.54 which is classified as low-level tendency. The group whose usage frequency was moderate (i.e. two to three hours a day) had juvenile delinquency tendency score of 67.16, classified as low-level tendency. Meanwhile, the group with low frequency of internet usage (i.e. between 0 to an hour a day) had average score of juvenile delinquency of 74.42 which can be classified as moderate-level tendency. In general, it implies that all subjects had low to moderate level of tendency for juvenile delinquency. Further post hoc analysis and Least Significant Difference (LSD) see Table 11, test resulted as follow:

1. There was a marked difference in juvenile delinquency tendency score between group of high internet usage and group of low internet usage.

2. There was a marked difference in juvenile delinquency tendency score between group of mediocre internet usage and group of low internet usage.

3. No notable difference in juvenile delinquency tendency score was found between group of high internet usage and group of moderate internet usage.

As shown in the result of hypothesis testing and in the mean values obtained from descriptive statistical data, the three groups with different level of internet usage also differed in their juvenile delinquency tendency and generally all subjects had low to moderate level of tendency for juvenile delinquency. Although the mean values of juvenile delinquency were in low and moderate category, this condition should be our concern because it still indicates the presence of juvenile delinquency. It occurs due to, among other things, the use of the internet which has both its advantages and disadvantages. Similarly, Young (1988) states that excessive use of the internet can result in unfavorable experience. Uncontrolled use of internet may also affect the academic life of adolescents. As Budhyati (2012) suggests, juvenile delinquencies that may be caused by the internet are skipping school due to staying all night for online gaming. Adolescents might also lie to their parents because internet addiction demands money for the bill of internet café or of home internet service. In addition, the subjects of this research also reported playing truant and stealing which supports the suggestion of Budhyati about the probable consequences of internet usage.

Result also shows that Facebook is the second most accessed internet-based social media by adolescents. The usage of Facebook per se also has a repercussion as stated by Andina (2010), which is the development of antisocial personality (i.e. inclination to behave in a fashion that contradict the social norms). According to the Indonesian Guidelines for Classification and Diagnosis of Mental Disorder (Pedoman Penggolongan dan Diagnosis Gangguan Jiwa [PPDGJ]), such personality trait in adolescents is characterized by tendency to act against school or home regulations, for instance lying, stealing, and vandalism. In other words, people with antisocial personality tends to move against the norms of their community. It is possible that the negative 
behaviors reported by the subjects of this research, such as disobeying parents or teachers, leaving home without parents' permission, theft and vandalism, occurred because of uncontrolled usage of the internet among adolescents.

\section{References}

DETIK COM, 6 Bulan, Angka Kriminal Anak di Bawah Umur Tinggi, Date of access: 20/4/2012. http://surabaya.detik.com/read/ 2009/09/01/091523/1193666/466/6-bulan-angka-kriminal-anak-di-bawahumur-tinggi.

American Psychiatric Association, 2013, Diagnostic and Statistical Manual of Mental Disorders, Fifth Edition (DSM-5) (Arlington, VA: American Psychiatric Association).

Andina, E., 2010, Studi dampak negatif facebook terhadap remaja Indonesia. Aspirasi, 1(1), 119-146.

Badan Pusat Statistik (BPS). https://www.bps.go.id/website/pdf_publikasi/profil-kriminalitas-remaja-2010

Budhyati, A., 2012, Pengaruh internet terhadap kenakalan remaja. Prosiding Seminar Nasional Aplikasi Sains \& Teknologi Periode III, 426-434

NUSANTARAKU, Jumlah Anak dan Remaja Pelaku Kriminal, Data of access: 17/4/2011. http://www.nusantaraku.org/forum/archive/index.php/t-16476.htm.

Monks, F.J., Knoers, A.M.P., Haditono, S.R., 2002, Psikologi Perkembangan : Pengantar Dalam Berbagai Bagiannya (Yogyakarta, Indonesia: Gadjah Mada University Press)

Sarwono, S., Meinarno, E, 2010, Psikologi Remaja (Jakarta, Indonesia: Salemba Humanika).

KOMINFO, Siaran Pers Tentang Riset Kominfo dan UNICEF Mengenai Perilaku Anak dan Remaja Dalam Menggunakan Internet, Date of Access: 24/10/2015. http://kominfo.go.id/index.php/content/detail/3834/Siaran+Pers+No.+17-PIH-KOMINFO-2-

2014+tentang+Riset+Kominfo+dan+UNICEF+Mengenai+Perilaku+Anak+dan+Remaja+Dalam+Menggunakan +Internet+/0/siaran_pers\#.Vit_Wyub4rE.

Young, K. S., 1998, Internet addiction: The emergence of a new clinical disorder. CyberPsychology \& Behavior, 1(3), 237-244. 